noteworthy. The continuing research on materials, design of concrete structures, and on methods of construction is adequately catalogued. On the materials side are discussed fundamental properties of unstressed concrete; properties of concrete under stress; durability of concrete; X-ray diffractometry of cement minerals; the system $\mathrm{CaO}-\mathrm{Al}_{2} \mathrm{O}_{3}-\mathrm{SO}_{3}$; hydration of cement; problems of chemical analysis of cement and concrete; research on concrete under stress; elasticity of high-strength concrete; damping capacity; concrete strength testing; relationship between bending strength of reinforced concrete beams and concrete cube strength; perlite aggregate concrete; and dimensional changes in unloaded concrete. In the section recording research on design of structures, among other subjects, mention is made of the work on bridges; doubly curved shell roofs; ultimate load behaviour of framed structures; analysis of shear walls in multi-storey structures; and model testing of structures. Methods of construction include work on factors affecting appearance of concrete surfaces; on omission of expansion joints from concrete roads; on skidding resistance; and on no-fines concrete for paving. Looking ahead, there is immense scope for development of precast concrete structural units based on standard mould sizes; the increased capacity planned for production of highquality concrete facing blocks should materially help to relieve the present shortage of building bricks.

\section{Prestressed Concrete and Machinery Structures}

A symposium on the "Application of Prestressed Concrete to Machinery Structure" was held during January 14-15, 1964, at the Conference and Training Centre of the Cement and Concrete Association, Wexham Springs, Slough, Buckinghamshire, on behalf of the Committee set up to exanine this subject by the Fédération Internationale de la Préconstrainte. The Proceedings of this symposium have recently been published by the Prestressed Concrete Development Group (Pp. 40. London: Prestressed Concrete Development Group, 1965. 25s.). Following a brief address of welcome by A. R. Collins (director, Research and Technical Services, Cement and Concrete Association), the opening address was delivered by Y. Guyon (president, Fédération Internationale de la Préconstrainte) wherein he described the subject as ". . . certainly a fascinating one, and the field so far is almost virgin, with a tremendous potential for development". The papers which followed were: "Prestressed Concrete and its Relevance to Machine Frames" by A. J. Harris; and "Local and Bearing Stresses" by R. E. Rowe. Under the general heading "Applications of Prestressed Concrete to Machinery Structures", six papers were presented: "Power Stations" by C. D. Crosthwaite; "Dynamie Loading" by J. H. A. Crockett; "Some Structures subject to Shock Loading" by F. Walley; "Foundations for Heavy Plant" by Th. Hinckeldey and R. Oppermann (West Germany); "Presses and Plant for Heavy-Metal Cutting" by J. T. Lewis; and "Triaxially Prestressed Bedplates or Heavy Frames" by I. G. Ludkovsky (U.S.S.R.). The summing up and general conclusions reached at this symposium were left to A. J. Harris and are given at the end of this publication, which certainly breaks new ground and for this reason alone is an important contribution to our knowledge of the use and scope of prestressed concrete.

\section{Magnetism Group}

The Council of the Institute of Physics and the Physical Society has announced the establishment of a Magnetism Group. The aim of the new Group is to further interest in magnetism by holding regular discussion meetings and in other ways. It is intended that these meetings shall be of relevance to physicists from industry, Government establishments and academic institutions and co-operation will be maintained with other specialist groups of the Institute and Society, and with similar groups at home and abroad. The first meeting of the new Group will be held in December 1965 and further details will be announced later. The following have been appointed as the provisional Committee and granted power to co-opt additional members: Dr. W. M. Lomer (chairman); Prof. E. B. Wohlfarth (honorary secretary); Dr. G. G. E. Low; Mr. R. D. Lowde and Dr. W. Marshall. Further information, including details of membership of the Institute and Society and of its Magnetism Group, can be obtained from the Registrar, the Institute of Physics and the Physical Society, 47 Belgrave Square, London, S.W.1.

\section{Announcements}

Mr. R. ORGAN, formerly chief experimental officer in the research laboratories of the British Museum, has been appointed curator of conservation at the Royal Ontario Museum.

THE bicentennial celebration commemorating the birth of James Smithson will be held at the Smithsonian Institution during September 16-18. Further information can be obtained from the Smithsonian Institution, The Mall, Washington 25, D.C.

A symposium on "Insect Behaviour", arranged by the Royal Entomological Society of London, will be held at the Imperial College of Science and Technology during September 23-24. Further information can be obtained from the Registrar, Royal Entomological Society of London, 41 Queen's Gate, London, S.W.7.

A symposiom on "The Soil Resources of Tropical Africa", organized by the African Studies Association of the United Kingdom, will be held at University College, London, on September 29. Further information can be obtained from Prof. J. D. Fage, Centre of West African Studies, University of Birmingham, Birmingham 15.

A CONFERENCE on "Optics in Space", arranged by the Optical Group of the Institute of Physies and the Physical Society, will be held at the University of Southampton during September 27-30. Further information can be obtained from the Meetings Officer, Institute of Physics and the Physical Society, 47 Belgrave Square, London, S.W.1.

A CONFERENCE on "Non-metallic Thin Films", arranged by the Electronics Group of the Institute of Physics and the Physical Society, will be held at Chelsea College of Scionce and Technology during September 23-24. Further information can be obtained from the Meetings Officer, Institute of Physics and the Physical Society, 47 Belgrave Square, London, S.W.1.

THE twentieth annual "Electronics, Instruments, Controls and Components Exhibition and Convention" of the Institution of Electronics (Northern Division) will be held at Belle Vue, Manchester, during September 28October 2. Further information can be obtained from Mr. W. Birtwistle, Institution of Electronics, 78 Shaw Road, Rochdale, Lancashire.

CORRIGENDUM. In the article entitled "Mitosis in Hybrid Cells derived from Mouse and Man" by Prof. $\mathrm{H}$. Harris et al., which was published on p. 606 of the August 7, 1965 , issue of Nature, the blocks for Figs. 1 and 2 should be interchanged. The legends should stand as at present.

ERRATUM. In the article entitled "Correlation between Coding-triplets and Amino-acids" by Dr. S. R. Pelc, which appeared on p. 597 of the August 7, 1965, issue of Nature, lines 8 and 9 of the second paragraph should read ". . . No amino-acid in these columns contains a methyl group". 